\title{
Concentrate levels for lambs grazing on buffel grass ${ }^{1}$
}

\section{Doses de concentrado para cordeiros mantidos em pastos de capim-bufel}

\author{
Tadeu Vinhas Voltolini²*, Salete Alves de Moraes $^{3}$, Gherman Garcia Leal de Araújo ${ }^{3}$ e Luiz Gustavo Ribeiro \\ Pereira $^{4}$
}

\begin{abstract}
Use of concentrate for lambs grazing buffel grass may improve animal performance and animal traits. The objective of the present trial was to evaluate the final body weight, average daily gain, total weight gain and carcass traits (cold and hot carcass weights, cold and hot dressing percentages) of lambs grazing buffel grass and receiving different concentrate levels $(0 ; 0.33 ; 0.66$ and $1.0 \%$ of dry matter in relation to body weight). Forty lambs were used, ten animals by treatment, with $16.5 \pm 2.0 \mathrm{~kg}$ of initial body weight, distributed in four groups. Experimental design was a completely randomized with ten replicates. Concentrate levels did not influence the final body weight, the average daily gain, total weight gain and cold and hot carcass weights. However, the increase of concentrate levels promoted higher cold and hot carcass yields.
\end{abstract}

Key words - Cenchrus ciliaris. Concentrate supplementation. Lamb supplementation.

\begin{abstract}
Resumo - O uso de concentrados para ovinos mantidos em pastagens de capim-bufel pode melhorar o desempenho produtivo e os parâmetros de carcaça dos mesmos. O objetivo do presente estudo foi avaliar o peso corporal final, o ganho médio diário e ganho de peso total além dos parâmetros de carcaça (pesos e rendimentos de carcaça quente e fria) de ovinos mantidos em pastos de capim-bufel recebendo doses crescentes de suplemento concentrado $(0 ; 0,33 ; 0,66$ e $1,0 \%$ na matéria seca do suplemento em relação ao peso corporal dos animais). Foram utilizados 40 ovinos machos, dez animais por tratamento, com peso corporal inicial médio de $16,5 \pm 2,0 \mathrm{~kg}$, distribuídos em quatro grupos. O delineamento experimental adotado foi o inteiramente casualizado com dez repetições. As doses de concentrado não influenciaram o peso corporal final, o ganho médio diário, o ganho de total, os pesos de carcaça quente e fria. Entretanto, o aumento nas doses de concentrado proporcionaram maiores rendimentos de carcaça quente e fria.
\end{abstract}

Palavras-chave - Cenchrus ciliaris. Suplementação com concentrado. Suplementação de cordeiros.

\footnotetext{
* Autor para correspondência

${ }^{1}$ Recebido para publicação em 13/10/2009; aprovado em 21/01/2011

Pesquisa financiada pelo Banco do Nordeste do Brasil

${ }^{2}$ Embrapa Semiárido, Petrolina-PE, Brasil, tadeu.voltolini@cpatsa.embrapa.br

3Embrapa Semiárido, Petrolina-PE, Brasil, salete.moraes@cpatsa.embrapa.br,ggla@cpatsa.embrapa.br

${ }^{4}$ Embrapa Gado de Leite, Juiz de fora-MG, Brazil, luiz.gustavo@cnpgl.embrapa.br
} 


\section{Introduction}

Sheep production is one of the most important economic activities of Brazilian semi-arid. However, the production system in this region is characterized as extensive, showing low stocking rate of native pastures, low meat and milk yield, low reproductive efficiency and high mortality rate of herds, resulting in a low economic performance to farmers (MOREIRA et al., 2008; VOLTOLINI et al., 2009).

In this region, there are few alternatives to produce feed to herds especially during dry rainy transition period or dry period of the year. Buffel grass (Cenchrus ciliaris L.) is one of them (GUIMARÃES FILHO; SOARES, 1999; SOUZA; ESPÍNDOLA, 2000; SANTOS et al., 2005). According to Souza and Espíndola (1999) this pasture may produces more than $4,500 \mathrm{~kg} \mathrm{year}^{-1}$ of dry matter. On the other hand, in the dry rainy or in dry period of year this forage may show poor quality (MOREIRA et al., 2007) affecting productive performance of animals (SOUZA; ESPÍNDOLA, 2000).

Use of concentrate supplementation may increase the productive performance and carcass traits of lambs grazing buffel grass (ANDRADE et al., 2007), especially for high genetic merit animals. Carvalho et al. (2007) observed higher total weight gain, final body weight and average daily gain of lambs grazing Tifton 85 grass receiving increasing levels of concentrate. Similar responses were observed by Andrade et al. (2007) who evaluated the productive performance of lambs grazing native pastures and receiving increasing levels of concentrate in Brazilian Northeast semi-arid.

Therefore, the objective of this present study was to evaluate the productive performance and carcass traits of lambs grazing buffel grass receiving increasing levels of concentrate.

\section{Material and methods}

The present trial was carried out at "Campo Experimental da Caatinga" of Embrapa Tropical Semi-Arid in Petrolina-PE. Four concentrate levels $(0 ; 0.33 ; 0.66$ and $1.0 \%$ of supplement in relation to body weight) were compared. Four hectares of buffel grass were used, divided in four paddocks of 1.0 ha. Ten lambs were distributed by paddock. In each week the animals were changed of the paddocks.

Petrolina's climate is Bswh' semi-arid, according to Köeppen classification. Climate data registered (air temperatures, relative air humidity, rain precipitation, evapotranspiration and solar radiation) during the experimental period are shown in Table 1.

Soil of area is classified as yellow argisol showing the follow characteristics in the initial phase of experimental trial: $\mathrm{pH}=5.70$; organic matter $=11.17 \mathrm{~g} \mathrm{~kg}^{-1}$; phosphorus $(\mathrm{P})=5 \mathrm{mg} \mathrm{dm}^{-3}$; potassium $(\mathrm{K})=0.36 \mathrm{cmol}_{\mathrm{c}} \mathrm{dm}^{-3}$; calcium $(\mathrm{Ca})=1.40 \mathrm{cmol}_{\mathrm{c}} \mathrm{dm}^{-3}$; magnesium $(\mathrm{Mg})=0.70 \mathrm{cmol}_{\mathrm{c}} \mathrm{dm}^{-3}$; alluminium $(\mathrm{Al})=0.10 \mathrm{cmol} \mathrm{dm}_{\mathrm{c}}^{-3}$; hidrogen and alluminium $(\mathrm{H}+\mathrm{Al})=2.97 \mathrm{cmol}_{\mathrm{c}} \mathrm{dm}^{-3}$; sum of bases $(\mathrm{SB})=2.50 \mathrm{cmol}_{\mathrm{c}}$ $\mathrm{dm}^{-3}$; cation exchange capacity $(\mathrm{T})=5.47 \mathrm{cmol}_{\mathrm{c}} \mathrm{dm}^{-3}$ and bases saturation $(\mathrm{V})=46 \%$.

Forage mass of pre and post graze were estimated using a frame in squared format $\left(1.0 \mathrm{~m}^{2}\right)$. Weekly, two samples of forage were collected in pre and post graze for each paddock, and the cuts were realized in the ground level of soil.

Leaves and stems mass were estimated by separation and quantification of dry weight of forage mass components (approximately 100g) in pre and post graze. Samples of entire plant, leaves and stems were weighted in natura and sent to dry matter determinations during 72 hours to $55{ }^{\circ} \mathrm{C}$. Crude protein, ash and in vitro digestibility of dry matter levels were determined according to methodologies describes by Silva and Queiroz (2002) while the levels of neutral detergent fiber and acid detergent fiber were determined according to Van Soest et al. (1991).

Tabela 1 - Climate characteristics registered during experimental period

\begin{tabular}{ccccccccc}
\hline \multirow{2}{*}{ Date } & \multicolumn{1}{c}{--------Air temperature $\left({ }^{\circ} \mathrm{C}\right)$-------- } & ------Relative air humdiity $(\%)$------ & RP $(\mathrm{mm})$ & EVP $(\mathrm{mm})$ \\
\cline { 2 - 8 } & Medium & Min. & Max & Medium & Min. & Max. & & \\
\hline May & 24.1 & 19.3 & 31.2 & 70.8 & 40.0 & 93.3 & 0 & 3.99 \\
June & 25.2 & 21.1 & 31.2 & 61.3 & 39.6 & 81.8 & 0 & 3.54 \\
July & 23.6 & 17.0 & 30.8 & 59.1 & 31.4 & 92.8 & 0 & 4.85 \\
August & 25.7 & 18.1 & 33.6 & 51.4 & 25.9 & 85.5 & 0 & 5.39 \\
\hline
\end{tabular}

Source: Automatic meteorological station - Campo experimental da Caatinga - Petrolina-PE. Min $=$ minimum, Max $=$ maximum, RP $=$ rain precipitation, $\mathrm{EVP}=$ evapotranspiration, $\mathrm{SR}=$ solar radiation 
Concentrate was formulated according to National Research Council (NRC, 2007) and offered once a day, at 8:00 hour A.M., to group of animals. The amount of supplement was adjusted daily to avoid amount of orts higher than $20 \%$ of the offered. Proportion of ingredients and chemical value of concentrates are showed in Table 2.

Supplement dry matter intake was calculated by the follow equation: $\mathrm{DMI}=\mathrm{S}-\mathrm{O}$, where $\mathrm{DMI}=$ supplement dry matter intake, $\mathrm{S}=$ amount of supplement and $\mathrm{O}=$ amount of orts, in dry matter basis.

Forty non-defined genotype lambs were used, ten by treatment, castrated, with initial body weight of $16.5 \pm 2.0 \mathrm{~kg}$. Experimental period extended from April to July 2008, during 70 days. Animals were weighted weekly, in the morning.

Total weight gain (TWG) was determined by the follow equation: $\mathrm{TWG}=\mathrm{FBW}-\mathrm{IBW}$, where: $\mathrm{FBW}=$ final body weight and IBW = initial body weight. The average daily gain was obtained by division of TWG by the number of days of experimental period, while the FBW was the weight obtained in the last weighting.

Table 2 - Proportion of ingredients and chemical composition of concentrate

\begin{tabular}{lc}
\hline \multicolumn{1}{c}{ Component } & Concentrate levels (\%) \\
\hline Dry ground corn & 34.0 \\
Wheat bran & 43.0 \\
Soybean meal & 18.0 \\
Urea & 1.0 \\
Mineral e vitamin mix & 4.0 \\
\hline \multicolumn{2}{c}{ Chemical composition (\% of dry matter) } \\
\hline Dry matter, \% as fed & 90.0 \\
Ash & 7.90 \\
Neutral detergent fiber & 27.7 \\
Acid detergent fiber & 11.1 \\
Crude protein & 20.0 \\
Total digestible nutrients & 75.0 \\
\hline
\end{tabular}

Before slaughter, animals were weighted and kept in fasting of solids for 16 hours. After slaughter the carcass were weighted and the carcass yield were calculated according the follow equation: $\operatorname{HCD}(\%)=$ $(\mathrm{HCW} / \mathrm{SBW}) \times 100$, where $\mathrm{HCD}=$ hot carcass yield, $\mathrm{HCW}=$ hot carcass weight and $\mathrm{SBW}=$ slaughtered body weight.
Experimental design was a completely randomized with ten replicates by treatment. Statistical analyses were realized by Statistical Analyses System (SAS, 1999), using variance analyses and linear regression.

\section{Results and discussion}

Forage mass of buffel grass pastures found in this present study (FIG. 1) is in accordance to the results obtained by Moreira et al. (2007) who evaluated productive potential of dormant buffel grass and reported forage mass values of 3,076 to $3,118 \mathrm{~kg}$ of DM ha ${ }^{-1}$ during November and December in Brazilian Northeast semi-arid.

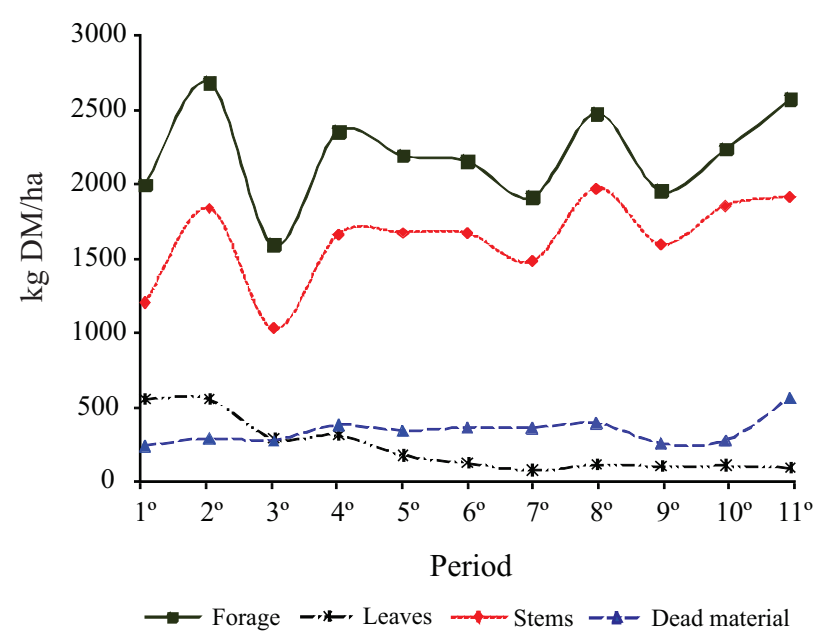

Figure 1 - Forage, leaves, stems and dead material mass of buffel grass grazing by lambs receiving increasing levels of concentrate during the experimental period

Proportion of leaves, stems and dead material were similar to the results found by Souza and Espíndola (1999). In the initial phase of this trial, the leaf fraction corresponded to $28 \%$ of forage mass while the stem and dead material corresponded to $60 \%$ and $12 \%$ of forage mass, respectively. On the other hand, at the end of the experimental period, the fractions of leaf, stem and dead material corresponded to $4 \%, 75 \%$ and $22 \%$ of forage mass, respectively, reducing the leaf mass and increasing the stem and dead material mass.

Besides the reduction of leaf mass, the remaining leaves in the sward were found in the base of forage plant, harming the access and harvesting by the animals, promoting structural and morphological 
changes in the plant, reducing forage dry matter intake and productive performance of animals.

Santos et al. (2005) evaluated morphological composition in extrusa samples of bovines grazing buffel grass in Brazilian Northeast semi-arid and reported a reduction in proportion of leaves $(59.92 \%$ to $29.43 \%)$ and the increasing of stems $(22.33 \%$ to $52.00 \%)$. These results obtained by Santos et al. (2005) are in accordance the data observed in the present trial, indicating a drastic reduction of leaf and increase of stem and dead material in the forage mass, promoting a longer grazing time in the dry rainy transition period or in dry transition period. This change in the structural and morphological composition of forage plant, affect the harvest by animal and diet quality.

In general, buffel grass used in this study showed poor chemical composition (FIG. 2), with low levels of crude protein $(\mathrm{CP})$ and in vitro dry matter digestibility (IVVDM) and high levels of dry matter (DM), neutral detergent fiber (NDF) and acid detergent fiber (ADF). During the experimental period were observed increase in organic matter (OM), NDF, ADF levels and decrease in ash, CP, IVVDM levels, demonstrating that the advanced in graze time of the paddocks and maturity stage of plants harmed the chemical composition of buffel grass.

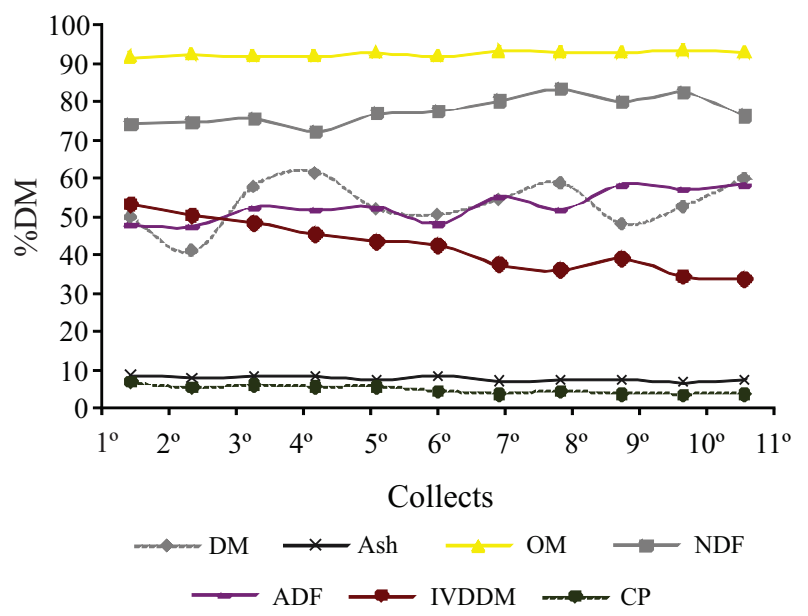

Figure 2 - Chemical composition of buffel grass during experimental period grazed by lambs receiving increasing levels of concentrate. $\mathrm{DM}=$ dry matter, Ash, $\mathrm{OM}=$ organic matter, NDF $=$ neutral detergent fiber, $\mathrm{ADF}=$ acid detergent fiber, IVDDM = in vitro digestibility of dry matter digestibility, $\mathrm{CP}=$ crude protein

Dantas Neto et al. (2000) evaluated the chemical composition of buffel grass cut in different plant ages and they observed a reduction in CP and increase of DM levels with the advance of buffel grass age. Cutting buffel grass with intervals of 35 days, the $\mathrm{CP}$ and DM levels were $34.97 \%$ and $12.30 \%$, respectively, although when the forage was cut with 95 days of interval, the DM and CP levels were $47.91 \%$ and $6.96 \%$, respectively.

Santos et al. (2005) determined chemical composition of buffel grass in Brazilian Northeast semi-arid and they reported values of $63.0 \%$ to $83.6 \%$; $5.23 \%$ to $3.37 \% ; 74.23 \%$ to $73.41 \% ; 57.47 \%$ to $55.41 \%$; $5.14 \%$ to $7.11 \% ; 88.55 \%$ to $88.12 \%$ and $14.32 \%$ to $14.81 \%$ to, respectively, DM, CP, NDF, ADF, ash, total carbohydrates (TCHO) and non fibrous carbohydrate (NFC) during the dry period of year. These values are presented by Santos et al. (2005) are in according with the results obtained in the present study and show that buffel grass in this period is a forage that contains high levels of DM, NDF, NDA and low levels of CP.

In this study, concentrate supplementation containing high levels of protein may be an important tool to increase dry matter intake and digestibility of fibrous fractions of forage, also to improve the productive performance of lambs in the rainy-dry transition period and in dry period of year (MORAES et al., 2006; MOREIRA et al., 2004; RUAS et al., 2000; ZANETTI et al., 2000). In the present trial, the CP level used in concentrate was $20.0 \%$ of DM.

Concentrate levels did not influence $(\mathrm{P}>0.05)$ final body weight, average daily gain and total weight gain of lambs grazing buffel grass (TAB. 3). Average daily gain of lambs was $.053 \mathrm{~kg}$ in average. This result is lower than the productive performance reported by Andrade et al. (2007), who found an average daily gain variation of 0.10 to $0.20 \mathrm{~kg}_{\text {animal }}{ }^{-1} \mathrm{day}^{-1}$ of Santa Ines lambs grazing native pasture enriched with buffel grass, receiving increasing levels of concentrate, this can be possibly due to the better chemical composition of buffel grass used in this study.

On the other hand, the results found were higher than the presented by Santos and Espíndola (2000) who evaluated the productive performance of lambs grazing dormant buffel grass exclusively or dormant buffel grass enriched with legumes and they also observed an average daily gain of 0.012 to $0.050 \mathrm{~kg} \mathrm{animal}^{-1} \mathrm{day}^{-1}$, resulting in a low productive performance of animals during the experimental period.

Using 10 animals ha-1, like in the present study, Souza and Espíndola (2000) related an average daily gain variation of .012 and $.017 \mathrm{~kg}^{\text {animal }}{ }^{-1} \mathrm{day}^{-1}$, while using 4 animals ha $^{-1}$, the average daily gain reported was .027 to $.050 \mathrm{~kg}$ animal ${ }^{-1}$ day $^{-1}$ suggesting the use of moderate stocking rate in the pastures of buffel grass in dry or rainy-dry period to improve the individual performance of lambs or to maximize the period of use of dormant buffel grass pastures. 
Table 3 - Supplement intake and productive performance of lambs grazing buffel grass receiving increasing levels of concentrate

\begin{tabular}{lrrrrrc}
\hline \multirow{2}{*}{ Component } & \multicolumn{4}{c}{ Concentrate levels, \% body weight } & ER & $\mathrm{R}^{2}$ \\
\cline { 2 - 7 } & 0 & 0.33 & 0.66 & 1.0 & & - \\
\hline Supplement intake, kg animal ${ }^{-1}$ day $^{-1}$ & 0 & 0.06 & 0.13 & 0.20 & - & 38.15 \\
Final body weight, kg & 21.00 & 19.83 & 21.90 & 21.14 & $\hat{\mathrm{Y}}=20.97$ & 38.89 \\
Average daily gain, kg & 0.064 & 0.048 & 0.077 & 0.066 & $\hat{\mathrm{Y}}=0.064$ & 39.17 \\
Total weight gain, kg & 4.50 & 3.33 & 5.40 & 4.64 & $\hat{\mathrm{Y}}=4.47$ & 39 \\
\hline
\end{tabular}

$\mathrm{ER}=$ Equation of regression; $\mathrm{R}^{2}=$ Coefficient of determination

Voltolini et al. (2010) evaluated the productive performance of Brazilian Northeast semi-arid native lambs and reported an average daily gain variation of 0.025 to $0.047 \mathrm{~kg}$ animal ${ }^{-1}$ day $^{-1}$ in the dry period in the same region. These results are similar to the observed in the present trial and indicate a possibility to obtain low to moderate average daily gain in the dry or rainy dry period of year, promoting an opportunity to produce, to avoid weight loss or death of animals. The low average daily gain obtained in the present study resulted in a low final body weight and total weight gain in period in relation to the results reported by Andrade et al. (2007).

Possibly, the absence of positive responses in productive performance of lambs receiving growing levels of concentrate may be in function of the substitution effect, representing the reduction of forage dry matter intake by concentrate intake. This effect was reported by Voltolini et al. (2009) who found reduction of $18 \%$ to $28 \%$ in forage intake by increase of concentrate intake to lambs grazing Tifton 85 grass.

This reduction in forage intake promoted the absence of positive responses in productive performance of lambs grazing Tifton 85 grass and receiving concentrate supplementation. In another study proposed by Souza et al. (2008) to evaluated the productive performance of lambs grazing Tifton 85 grass and receiving $0 ; 0.66$; 1.33 and $2.0 \%$ of concentrate (dry matter basis), it was also observed the presence of substitution effect, however in this case the degree of this effect did not affect the productive performance of animals, possibility to obtain higher average daily gain, total weight gain and final body weight, using higher levels of concentrate.

Results are not in according with Carvalho et al. (2007) who evaluated the productive performance of lambs grazing Tifton 85 grass, receiving increasing levels of concentrate. These authors observed an increasingly weight gain and final body weight using $2.5 \%$ of concentrate in relation to body weight of animals and therefore, the same was observed by Souza et al. (2008) using $0.66 \% ; 1.33 \%$ and $2.0 \%$ of concentrate for lambs grazing irrigated Tifton 85 grass in Brazilian Northeast semi-arid. However, Carvalho et al. (2007) used Texel animals and Souza et al. (2008) used Santa Ines animals, these breeds are more specialized in meat production in relation to the present study that used native breeds.

Nevertheless, the productive performance of lambs obtained in present study may be harmed by the reduction of leaves in forage mass and decrease in chemical composition of forage observed especially in the final phase of this study. In this case, the concentrate offered may be considered the principal source of nutrients to animals while the pastures may be promoting little contribution in supply of nutrients to animals.

In the first and second period (42 days) the average daily gain of lambs was $66 \mathrm{~g}$ animal $^{-1}$ day $^{-1}$ while in third and fourth experimental the average daily gain was 53 and $36 \mathrm{~g}$ animal $^{-1}$ day $^{-1}$ (FIG. 3). This reduction in average daily gain probably was due the reduction in leaf mass and forage quality.

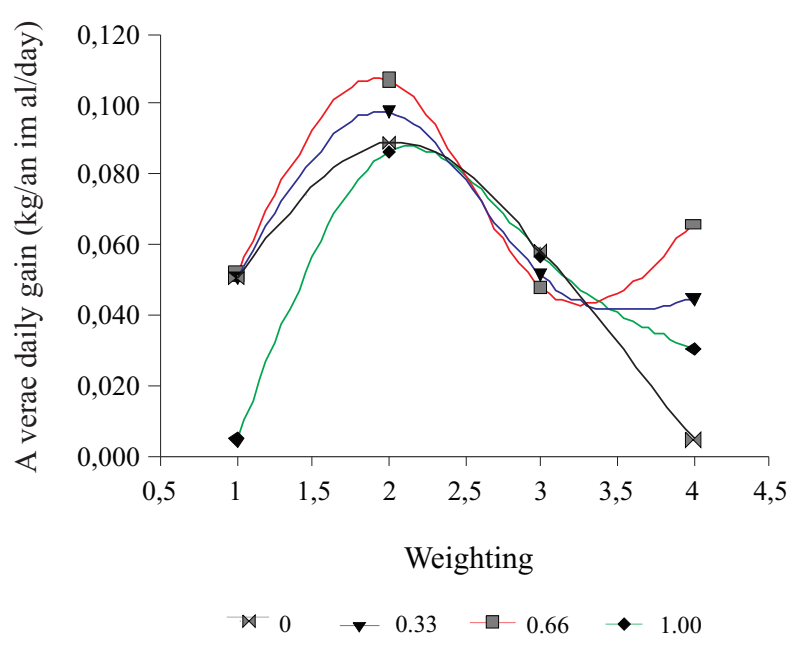

Figure 3 - Average daily gain of lambs grazing buffel grass in rainy-dry transition period receiving increasing levels of concentrate 
Table 4 - Hot and cold weights and yields of carcass of lambs grazing buffel grass pastures receiving growing levels of concentrate

\begin{tabular}{|c|c|c|c|c|c|c|}
\hline \multirow{2}{*}{ Component } & \multicolumn{4}{|c|}{ Concentrate levels, $\%$ body weight } & \multirow[t]{2}{*}{ ER } & \multirow[t]{2}{*}{$\mathrm{R}^{2}$} \\
\hline & 0 & 0.33 & 0.66 & 1.0 & & \\
\hline Hot carcass weight, $\mathrm{kg}$ & 7.75 & 7.57 & 8.46 & 8.22 & $\hat{\mathrm{Y}}=8.22$ & - \\
\hline Cold carcass weight, $\mathrm{kg}$ & 7.42 & 7.28 & 8.15 & 7.93 & $\hat{\mathrm{Y}}=7.93$ & - \\
\hline Hot carcass yield, \% & 36.84 & 38.06 & 38.64 & 38.86 & $\hat{\mathrm{Y}}=37.00+1.99 * \mathrm{C}$ & 0.10 \\
\hline Cold carcass yield, $\%$ & 35.26 & 36.60 & 37.21 & 34.47 & $\hat{\mathrm{Y}}=35.55+2.18 * \mathrm{C}$ & 0.12 \\
\hline
\end{tabular}

$\mathrm{ER}=$ Equation of regression; $\mathrm{R}^{2}=$ Coefficient of determination; $\mathrm{C}=$ concentrate

Concentrate levels did not influence $(\mathrm{P}>0.05)$ hot and cold carcass weights, however increase of concentrate promoted higher $(\mathrm{P}<0.05)$ cold and hot carcass yields (TAB. 4). These similar results for hot and cold carcass weights may be justified by similar final body weight.

Voltolini et al. (2009) who evaluated carcass traits of Santa Ines lambs grazing Tifton 85 grass with or without concentrate supplementation and were not found differences between hot carcass weight to supplemented or non-supplemented and justify these results by similar final body weight observed. On the other hand, these results are not according with Carvalho et al. (2007) and Souza et al. (2008) who evaluated the carcass traits of lambs grazing tropical pastures receiving increasing levels of concentrate and observed higher cold and hot carcass weights with greater levels of concentrate. In Carvalho et al. (2007) and Souza et al. (2008) studies, higher carcass weights can be justified by higher final body weight of lambs obtained by use of greater levels of concentrate.

Higher cold and hot carcass yields $(\mathrm{P}<0.05)$ were observed with increasing concentrate supplementation levels. Probably, these results can be explained due to higher fat levels obtained using greater concentrate levels. In this study, the results for the cold and hot carcass yields were low, probably because it was used native breed animal.

Besides, use of empty body weight to calculate carcass yield could be result in higher cold and hot carcass yield to supplemented lambs in comparison with non-supplemented animals, because exclusively use of forage promote greater gastrointestinal content. Carvalho et al. (2005) observed weight gastrointestinal content of $6.56 \mathrm{Kg}$ to lambs fed exclusively pastures while weights of those fed with pasture and concentrate supplementation varied to 6.26 and $4.35 \mathrm{Kg}$, when were used 1.0 and 2.5 of supplements in relation to animal body weight, respectively.

\section{Conclusions}

1. Productive performance and cold and hot carcass weights were not affected by concentrate levels;

2. Use of concentrate promoted higher cold and hot carcass yields.

\section{References}

ANDRADE, I. S. et al. Parâmetros ecofisiológicos e desempenho de ovinos Santa Inês submetidos a diferentes tipos de sombreamento e a suplementação em pastejo. Ciência e Agrotecnologia, v. 31, n. 02, p. 540-547, 2007.

CARVALHO, S. et al. Avaliação da suplementação concentrada em pastagem de Tifton- 85 sobre os componentes não-carcaças de cordeiros. Ciência rural, v. 35, n. 02, p. 435-439, 2005.

CARVALHO, S. et al. Desempenho e características da carcaça de cordeiros mantidos em pastagens de Tifton 85 e suplementados com diferentes níveis de concentrado. Revista Brasileira de Agrociência, v. 12, n. 03, p. 357-361, 2007.

DANTAS NETO, J. et al. Influência da precipitação e idade da planta na produção e composição química do capim Buffel. Pesquisa Agropecuária Brasileira, v. 35, n. 09, p. 1867-1874, 2000.

GUIMARÃES FILHO, C.; SOARES, J. G. G.. Avaliação de um modelo físico de produção de bovinos no semi-árido integrando Caatinga, Buffel e Leucena. I. Fase de cria. Pesquisa Agropecuária Brasileira, v. 34, n. 09, p. 1721-1727, 1999.

MORAES, E. H. B. K. de. Níveis de proteína em suplementos para novilhos mestiços em pastejo durante o período de transição seca/águas. Revista Brasileira de Zootecnia, v. 35 , n. 05 , p. 2135-2146, 2006.

MOREIRA, F. B. Níveis de suplementação com sal mineral proteinado para novilhos nelore terminados em pastagens no período de baixa produção forrageira. Revista Brasileira de Zootecnia, v. 33, n. 06, p. 1814-1821, 2004. Suplemento.

MOREIRA, J. N. Potencial de produção de capim Buffel na época seca no semi-árido Pernambucano. Revista Caatinga, v. 20, n. 03, p. 22-29, 2007. 
MOREIRA, J. N. Alternativas de volumosos para caprinos em crescimento. Revista Brasileira de Saúde e Produção Animal, v. 09, n. 03, p. 407- 415, 2008.

NATIONAL RESEARCH COUNCIL. Nutrient requeriments of small ruminants. 7th. Washington: National Academic Press, 2007. 408 p.

RUAS, J. R. M. Efeito da suplementação protéica a pasto sobre o consumo de forragens, ganho de peso e condição corporal em vacas nelore. Revista Brasileira de Zootecnia, v. 29, n. 03, p. 930-934, 2000.

SAS INSTITUTE. SAS STAT user's guide : version 6.4. Cary, 1999.

SANTOS, G. R. de A. Caracterização do pasto de capim Buffel diferido e da dieta de bovinos durante o período seco no sertão de Pernambuco. Revista Brasileira de Zootecnia, v. 34, n. 02, p. $454-463,2005$.

SILVA, D. J.; QUEIROZ, A. C. Análise de alimentos: Métodos químicos e biológicos. 3. ed. Viçosa: Universidade Federal de Viçosa, 2002.

SOUZA, A. A. de.; ESPÍNDOLA, G. B. Efeito da suplementação com feno de leucena (Leucaena leucocephala (Larn)de Wit) durante a estação seca sobre o desenvolvimento ponderal de ovinos. Revista Brasileira de Zootecnia, v. 28, n. 06, p. 1424-1429, 1999.

SOUZA, A. A. de.; ESPÍNDOLA, G. B. Bandos de proteína de leucena e de guandú para suplementação de ovinos mantidos em pastagem de capim Buffel. Revista Brasileira de Zootecnia, v. 29 , n. 02 , p. $365-372,2000$.

SOUZA, P. P. S. de.; SIQUEIRA, E. R.de.; MAESTÁ, S. A. Ganho de peso, características de carcaça e dos demais componentes corporais de cordeiros confinados, alimentados com distintos teores de uréia. Ciência Rural, v. 34, n. 04, p. 1185-1190, 2004.

SOUZA, R. A. Desempenho produtivo de ovinos mantidos em pastagem de Tifton 85 recebendo doses crescentes de suplementação com concentrado In: Congresso Nordestino de Produção Animal, 5, 2008, Aracajú. Anais... Aracajú/SE, 2008. 1 CD-ROM.

VAN SOEST, P. J.; ROBERTSON, J. B.; LEWIS, B. A. Symposium: Carbohydrate methodology, metabolism and nutritional implications in dairy cattle. Journal of Dairy Science, v. 74, n. 10, p. 3583-3597, 1991.

VOLTOLINI, T. V. Fontes protéicas no suplemento concentrado de ovinos em pastejo. Acta Scientiarum Animal Sciences, v. 31, n. 01, p. 61-67, 2009.

VOLTOLINI, T. V.; ARAÚJO, G. G. L. de.; MORAES, S. A. Urea levels in multiple supplement for sheep grazing on buffel grass. Acta Scientiarum - Animal Sciences, v. 32, n. 04, p. 461-465, 2010.

ZANETTI, M. A. et al. Desempenho de novilhos consumindo suplemento mineral proteinado convencional ou com uréia. Revista Brasileira de Zootecnia, v. 29, n. 03, p. 935-939, 2000. 